Gut, 1968, 9, 633-637

\title{
Presence of a non-adrenergic inhibitory system in the human colon
}

\author{
A. CREMA, M. DEL TACCA, G. M. FRIGO, AND S. LECCHINI \\ From the Department of Pharmacology, University of Pisa, Italy
}

The presence in the intestinal wall of intramural non-adrenergic inhibitor neurones has been postulated by many workers. Burnstock, Campbell, Bennett, and Holman (1964) have reported that in the taenia coli of the guinea pig the inhibitory responses to transmural stimulation, which persist in the presence of bretylium and guanethidine, are mediated by intrinsic nerves which are distinct from the sympathetic and parasympathetic system.

According to Burnstock, Campbell, and Rand (1966) the taenia coli of the guinea pig is also innervated by intramural inhibitory nerves with their cell bodies in Auerbach's plexus. These nerves could be excited by electrical stimulation of the taenia or by the application of ganglion-stimulating drugs. The intramural inhibitory nerves had different properties from sympathetic adrenergic nerves. Relaxation to stimulation was maximal at about 5 pulses/sec and was not blocked by bretylium, guanethidine, or DMPP.

Bennett (1966) and Bennett, Burnstock, and Holman (1966) presented evidence for the existence in the guinea-pig taenia coli of inhibitory nerves distinct from sympathetic perivascular nerves. The evidence was based on the observation that the pattern of the inhibitory junction potential was not changed by antiadrenergic agents and the hyperpolarization produced by intramural stimulation was different from that produced by perivascular stimulation. Electrophysiological evidence of intestinal inhibitor nerves was reported also by Bülbring and Tomita (1967).

The existence of non-adrenergic inhibitor nerves in the stomach wall has been shown by Martinson (1965a and b), by Campbell (1966), and by Bülbring and Gershon (1967). An inhibition resulting from activation of non-adrenergic inhibitory neurones by transmural stimulation has recently been described in rabbit ileum by Day and Warren (1968).

All the results mentioned above were obtained from animal specimens. The present paper deals with similar studies in the human colon.

${ }^{1}$ Assisted by a grant from the Consiglio Nazionale delle Ricerche (Group of Gastroenterology).
METHODS

Experiments were carried out on some 36 preparations of descending colon from 12 patients of both sexes. As premedication the patients received atropine $(0.5 \mathrm{mg})$ and promethazine hydrochloride $(25$ to $50 \mathrm{mg})$. Anaesthesia was induced with intravenous thiopentone sodium (200 to $500 \mathrm{mg}$ ), maintained with nitrous oxide, and adequate relaxation was secured with intramuscular d-tubocurarine ( 30 to $45 \mathrm{mg}$ ) or succinylcholine $(50 \mathrm{mg}$ ).

Healthy muscle was obtained from postoperative specimens removed for carcinoma of the large intestine. Any bowel with obstruction was excluded. The resected colon was immediately immersed in ice-cold, gassed Krebs solution and removed to the laboratory. The colon was opened along the border of one taenia and the mucosa removed rapidly.

Longitudinal and circular strips about $4 \mathrm{~cm}$ long, $4 \mathrm{~mm}$ wide, and $2 \mathrm{~mm}$ thick, were removed. The muscle strips were set up in organ baths at $36^{\circ}$ in Krebs solution gassed with a $95 \% \mathrm{O}_{2}-5 \% \mathrm{Co}_{2}$ mixture, and placed under a tension of about $3 \mathrm{~g}$. In order to obtain a steady baseline it was found necessary to vary slightly the tension from strip to strip, the range of variation being 2 to $4 \mathrm{~g}$. The preparation was left for about $60 \mathrm{~min}$, by which time spontaneous activity had developed.

Recordings were made on a smoked drum with a direct writing isotonic lever (magnification 10 times) and a vibrator was used to overcome friction.

For stimulating the preparations, a pair of $\mathrm{Ag}$ sheets $(3 \mathrm{~cm} \times 0.5 \mathrm{~cm})$ were mounted in parallel facing the strip. The preparations were stimulated with rectangular pulses of $1 \mathrm{msec}$ duration at twice-threshold voltage. Stimulus frequencies of 1 to $10 / \mathrm{sec}$ were used.

The following drugs were used: acetylcholine chloride, adrenaline bitartrate, noradrenaline bitartrate, 5-hydroxy-tryf tamire-creatinine-sulphate, atropine sulphate, methysergide maleate, dibenamine, propranolol, tetrodotoxin (Sankyo). The concentrations refer to the salts.

\section{RESULTS}

Transmural stimulation with pulses of $1 \mathrm{msec}$ duration at a rate of 1 to $10 / \mathrm{sec}$ in a train lasting $30 \mathrm{sec}$ causes the longitudinal strips to relax in $22 \%$ of the cases and to contract in $78 \%$ (Fig. 1). No relationship between frequency of stimulation and type of response was observed. 


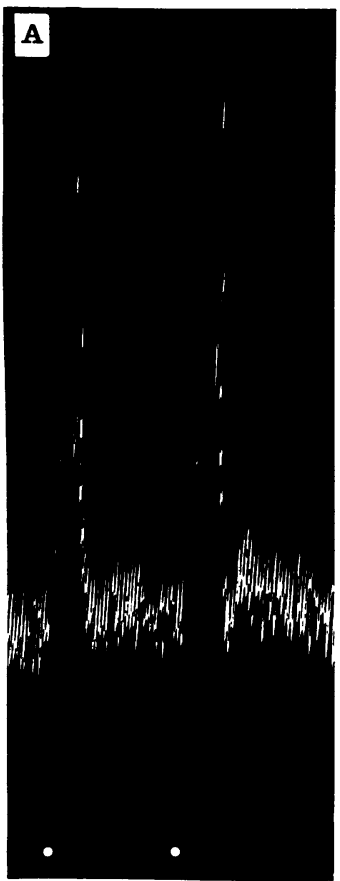

$\mathbf{T}_{3}$

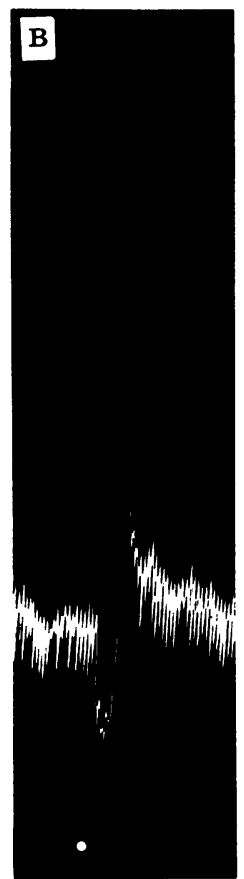

$\mathbf{T}_{3}$

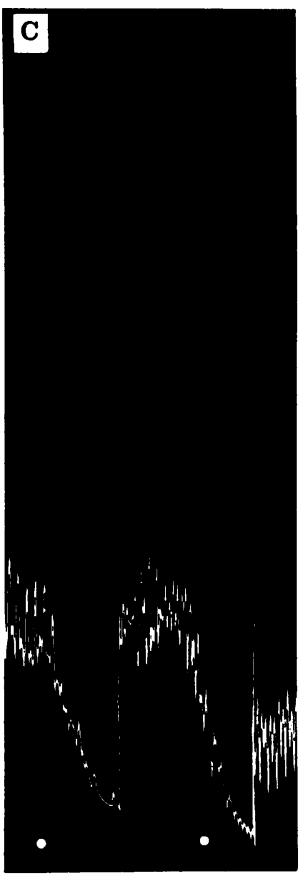

$\mathbf{N}$

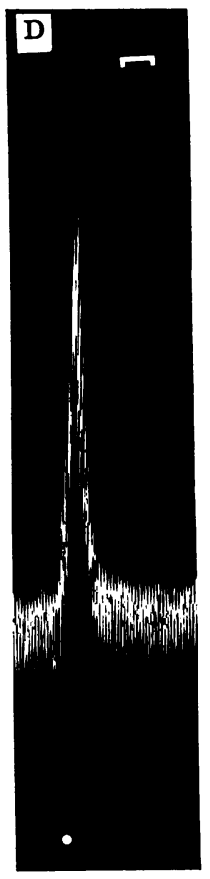

H T
FIG. 1. Isolated longitudinal strips of human colon. $T_{3}=$ supramaximal transmural stimulation $1 \mathrm{msec}, 30$ sec, $5 \mathrm{c} / \mathrm{sec} ; T_{2}=$ supramaximal transmural stimulation $1 \mathrm{msec}, 30$ sec, $10 \mathrm{c} / \mathrm{sec} ; N=$ noradrenaline $1 \cdot 10^{-7} \mathrm{~g} / \mathrm{ml} ; H T=$ $5 \mathrm{HT} 1 \cdot 10^{-5} \mathrm{~g} / \mathrm{ml}$. Note that transmural stimulation produces a contraction in $A$ and $a$ relaxation in $B$. Note that $5 \mathrm{HT}$ relaxes in $C$ but contracts in D. Time marker $=1 \mathrm{~min}$.
The low frequencies ( 1 to $5 / \mathrm{sec}$ ) caused the circular strips to relax in $70 \%$ of the experiments and to contract in $30 \%$. On the contrary, at higher frequencies (6 to $10 / \mathrm{sec}$ ), circular strips relaxed or contracted in equal percentages. These results suggest that low frequencies are more likely to elicit a relaxation response.

Atropine $\left(1 \cdot 10^{-8}\right.$ to $\left.1 \cdot 10^{-7} \mathrm{~g} / \mathrm{ml}\right)$, acting upon the circular and the longitudinal strips at all the frequencies of stimulation, did not affect relaxation, while reversing the contraction into relaxation (Figs. 2 and 3). The relaxation lasted through the entire period of stimulation. Cessation of stimulation was frequently followed by a large aftercontraction (Fig. 2). Similar aftercontractions have been reported by Burnstock et al (1966) and by Day and Warren (1968). Bennett (1966) has also observed an increase in amplitude of action potential and in rate of firing.

It must be mentioned that $1 \cdot 10^{-7} \mathrm{~g} / \mathrm{ml}$ of atropine completely blocked the response to acetylcholine (up to $1 \cdot 10^{-7} \mathrm{~g} / \mathrm{ml}$ ) without affecting muscle tone.

Among the mediators possibly involved in the transmural relaxation of the human colon are catecholamines and 5-hydroxytryptamine. In fact noradrenaline and adrenaline $\left(5 \cdot 10^{-7} \mathrm{~g} / \mathrm{ml}\right)$ caused both the circular and longitudinal strips to relax promptly and to cease all spontaneous movements (Fig. 1). However, pretreatment with $\alpha$ - and $\beta$-blocking agents (dibenamine $1 \cdot 10^{-6} \mathrm{~g} / \mathrm{ml}+$ propranolol $1 \cdot 10^{-6} \mathrm{~g} / \mathrm{ml}$ ) completely blocked the response to catecholamines (Fig. 2).

The response to 5-hydroxytryptamine $\left(1 \cdot 10^{-6}\right.$ to $1 \cdot 10^{-5} \mathrm{~g} / \mathrm{ml}$ ) was variable as shown in the Table and in Figure 1. Pretreatment with atropine $\left(1 \cdot 10^{-7} \mathrm{~g} / \mathrm{ml}\right)$

\section{TA B LE}

RESPONSE OF ISOLATED DESCENDING HUMAN COLON TO $5 \mathrm{HT}$

\begin{tabular}{|c|c|c|}
\hline & $\begin{array}{c}\text { Taenia coli } \\
(\%)\end{array}$ & $\begin{array}{c}\text { Circular Strip } \\
(\%)\end{array}$ \\
\hline Contraction & 61 & $\begin{array}{l}75 \\
25\end{array}$ \\
\hline $\begin{array}{l}\text { Contraction } \\
\text { Biphasic response (contraction followed } \\
\text { by relaxation) }\end{array}$ & 31 & - \\
\hline
\end{tabular}

reversed the contraction caused by 5-hydroxytryptamine to a relaxation, leaving the relaxation unaffected. The relaxation due to 5-hydroxytryptamine was not changed by $\alpha$ - and $\beta$-blocking agents, but was completely blocked by methysergide maleate $\left(1 \cdot 10^{-6} \mathrm{~g} / \mathrm{ml}\right)$ (Fig. 2).

However, the relaxation produced by transmural stimulation was unaffected by the simultaneous 


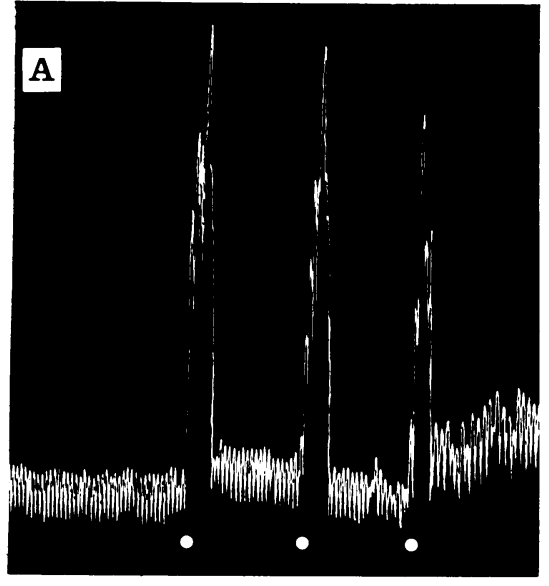

T:

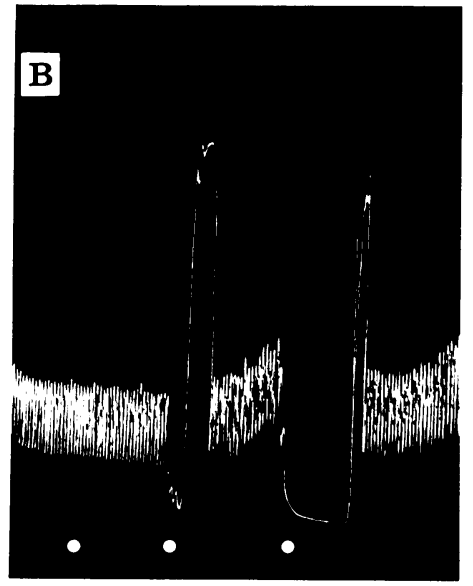

$\mathbf{N}$

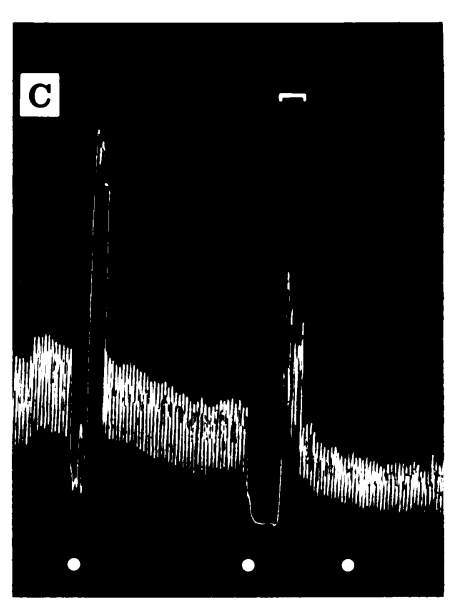

$\mathbf{T}_{\mathrm{j}}$

$\mathrm{T}_{.}$

H T

H(i. 2. Isolated longitudinal strips of human colon. $T_{1}-$ Supramaximal transmural stimulation l msec, 30 sec, 20 c/sec; $T_{.2}-$ Supramaximal transmural stimulation I msec, $30 \mathrm{sec}, 10 \mathrm{c} / \mathrm{sec} ; T_{3}$ - Supramaximal transmural stimulation I msec, $30 \mathrm{sec}, 5 \mathrm{c} / \mathrm{sec} ; T_{1}-$ Supramaximal transmural stimulation $\left.1 \mathrm{msec}, 60 \mathrm{sec}, 5 \mathrm{c} / \mathrm{sec} ; N-N o r a d r e n a l i n e ~ 5 \cdot l 0\right) \mathrm{g} / \mathrm{ml}$ : $H T=5 H T / \cdot I)^{5} \mathrm{~g} / \mathrm{ml}$.

Between $A$ and $B$ atropine $1 \cdot 10^{7} \mathrm{~g} / \mathrm{ml}+$ dibenamine and propranolol $1 \cdot 10^{6} \mathrm{~g} / \mathrm{ml}$. Between $B$ and $C-$ atropine, dibenamine, and propranolol as above + methysergide maleate $1 \cdot 10^{6} \mathrm{~g} / \mathrm{ml}$. Time marker $=1 \mathrm{~min}$.

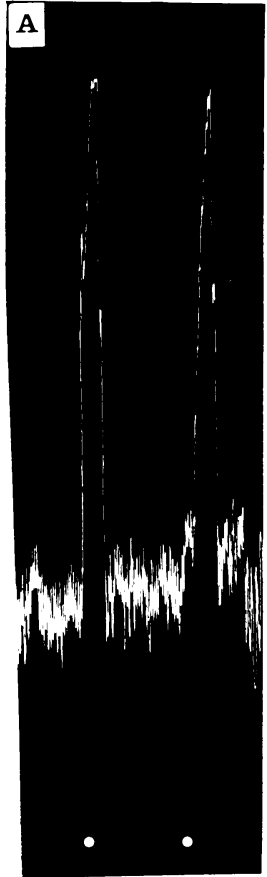

$\mathbf{T}_{?}$

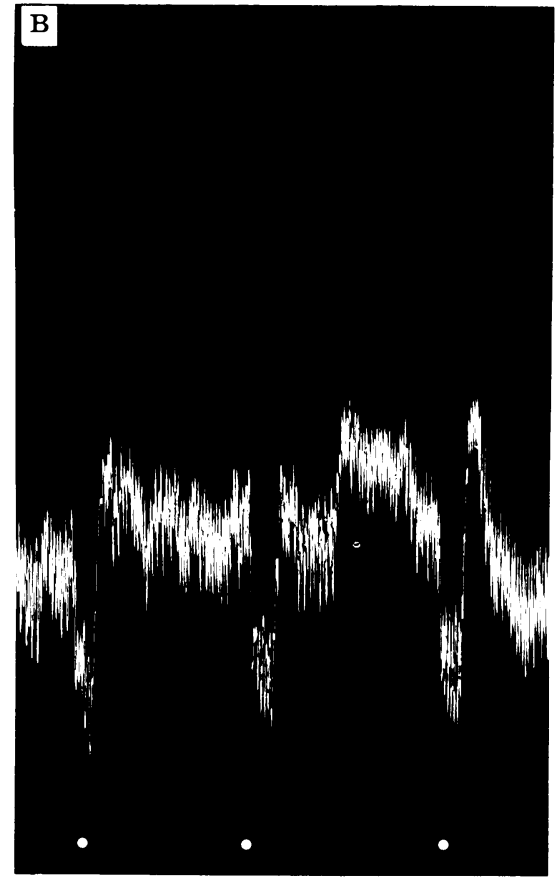

$\mathbf{T}_{1}$

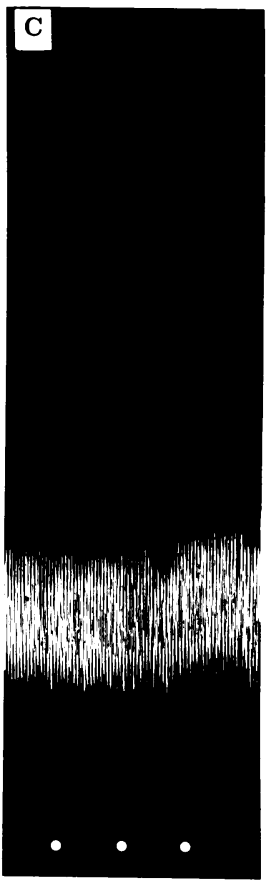

$\begin{array}{lll}\mathrm{T}_{1} & \mathrm{~T}_{2} & \mathrm{~T}_{3}\end{array}$

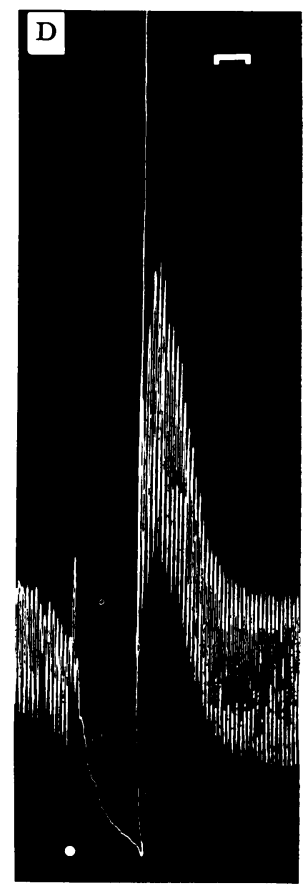

H T

Fig. 3. Isolated longitudinal strips of human colon. $T_{3} \quad$ Supramaximal transmural stimulation $1 \mathrm{msec}, 30 \mathrm{sec}, 5 \mathrm{c} / \mathrm{sec}$; $T_{2}-$ Supramaximal transmural stimulation $1 \mathrm{msec}, 30 \mathrm{sec}, 10 \mathrm{c} / \mathrm{sec} ; T_{1}=$ Supramaximal transmural stimulation $1 \mathrm{msec}, 30 \mathrm{sec}, 20 \mathrm{c} / \mathrm{sec} ; H T \cdots 5 H T 1 \cdot 10^{5} \mathrm{~g} / \mathrm{ml}$.

Between $A$ and $B$ - atropine $1 \cdot 10^{\circ} \mathrm{g} / \mathrm{ml}$. Between $B$ and $C$, and $C$ and $D=$ atropine $/ \cdot 10^{\circ} \mathrm{g} / \mathrm{ml}+t e t r o d o t o x i n$ $1 \cdot 1)^{6} \mathrm{~g} / \mathrm{ml}$. Time marker - I min. 
addition of atropine, $\alpha$ - and $\beta$-blocking agents plus methysergide maleate, added in a concentration adequate to block the response to acetylcholine, noradrenaline, and 5HT (Fig. 2).

Exposure of both longitudinal and circular strips to tetrodotoxin $\left(1 \cdot 10^{-6} \mathrm{~g} / \mathrm{ml}\right)$ for $30 \mathrm{~min}$ abolished the relaxation caused by electrical stimulation, both in the untreated and atropinized preparation, without abolishing the relaxation to 5HT (Fig. 3).

\section{DISCUSSION}

There is pharmacological evidence to indicate the presence of an inhibitory non-adrenergic system in the animal intestinal wall: our results seem to indicate that a similar system is present also in the human colon.

There is no consistent relationship between premedication and the type of response resulting from transmural stimulation. Furthermore, circular and longitudinal strips taken from the same colon can exhibit different responses.

It is difficult to understand how the inhibitory response to transmural stimulus could arise from a direct stimulation of the smooth muscle as the duration of the pulse is too short $(1 \mathrm{msec})$ and tetrodotoxin completely abolishes the relaxation.

The adrenergic system does not seem to be involved because $\alpha$ - and $\beta$-blocking agents are not able to abolish the relaxation due to transmural stimulation.

Other findings (Bianchi, Beani, Frigo, and Crema, 1968) obtained in the animal colon have shown that the inhibitory response elicited by electrical stimulation is not impaired by pretreatment in vivo with reserpine, $\alpha$-methyl-m-tyrosine, and perivascular denervation ex frigore, and by adding bretylium to the bath, inasmuch as in the guinea-pig colon $\alpha$ - and $\beta$-blocking agents are effective in blocking even the endogenous released catecholamines; it therefore seems likely that the same effect occurs in the human colon.

The site and type of action of 5-hydroxytryptamine on the digestive tract is different at the various levels. This amine can act directly on the smooth muscle according to Paton and Vane (1963), Fishlock, Parks, and Dewell (1965), Whitney (1965), Ulrich (1965) or indirectly according to Rocha e Silva (1953), Robertson (1953), Gaddum and Hameed (1954), Gaddum and Picarelli (1957), Day and Vane (1963), Brownlee and Johnson (1963), Ulrich (1965), Fishlock and Parks (1966), Gershon (1967), are Bülbring and Gershon (1967).

In the human colon the relaxing response to 5-hydroxytryptamine is poorly affected by tetrodotoxin, but is abolished by methysergide maleate which in turn is ineffective in blocking the relaxation response to transmural stimulation.

Therefore, the relaxing action of 5-hydroxytryptamine on the human colon seems to be direct and is not involved in the relaxation elicited by transmural stimulation, although, according to Bülbring and Gershon (1967), this amine may be a neurotransmitter impinging upon the inhibitory non-adrenergic neurones in the vagal supply to the stomach.

The sensibility of the inhibitory response to tetrodotoxin, acting on the sodium-dependent events (Narahashi, Moore, and Scott, 1964; Bülbring and Tomita, 1967; Kuriyama, Osa, and Toida, 1966), favours the view that nervous elements can be involved in this inhibition.

SUMMARY

Transmural stimulation of both circular and longitudinal strips from human colon causes a variable response. After atropine the response was always a relaxation, which was unaffected by $\alpha$ - and $\beta$-blocking agents and by methysergide maleate, which respectively abolish the inhibitory response to noradrenaline and 5HT. Tetrodotoxin completely inhibits relaxation, supporting the hypothesis that a non-adrenergic nervous pathway can be involved in the transmural relaxation.

\section{REFERENCES}

Bennett, M. R. (1966). Rebound excitation of the smooth muscle cells of the guinea-pig taenia coli after stimulation of intramural inhibitory nerves. J. Physiol. (Lond.), 185, 124-131.

Bennett, M. R., Burnstock, G., and Holman, M. E. (1966). Transmission from intramural inhibitory nerves to the smooth muscle of the guinea-pig taenia coli. Ibid., 182, 541-558.

Bianchi, C., Beani, L., Frigo, G. M., and Crema, A. (1968). Further evidence for the presence of non-adrenergic inhibitory structures in the guinea-pig colon. Europ. J. Pharmacol., 4, 51-61.

Brownlee, G., and Johnson, E. S. (1963). The site of the 5-hydroxytryptamine receptor on the intramural nervous plexus of the guinea-pig isolated ileum. Brit. J. Pharmacol., 21, 306-322.

Bülbring, E., and Gershon, M. D. (1967). 5-Hydroxytryptamine participation in the vagal inhibitory innervation of the stomach. J. Physiol. (Lond.), 192, 823-846.

smooth muscle as observed in the response to field stimulation of the guinea-pig taenia coli. Ibid., 189, 299-315.

Burnstock, G., Campbell, G., Bennett, H., and Holman, M. E. (1964). Innervation of the guinea-pig taenia coli: are there intrinsic inhibitory nerves which are distinct from sympathetic nerves? Int. J. Neuropharmacol., 3, 163-166.

,,-- Rand, M. J. (1966). The inhibitory innervation of the taenia of the guinea-pig caecum. J. Physiol. (Lond.), 182, 504526.

Campbell, G. (1966). The inhibitory nerve fibres in the vagal supply to the guinea-pig stomach. Ibid., 185, 600-612.

Day, M., and Vane, J. R. (1963). An analysis of the direct and indirect actions of drugs on the isolated guinea-pig ileum. Brit. $J$. Pharmacol., 20, 150-170.

Day, M. D., and Warren, P. R. (1968). A pharmacological analysis of the responses to transmural stimulation in isolated intestinal preparations. Ibid., 32, 227-240.

Fishlock, D. J., and Parks, A. G. (1966). The effect of 5-hydroxytryptamine on the human ileum and colon in vitro. Ibid., 28, 164-171. 
- - , Dewell, J. V. (1965). Action of 5-hydroxytryptamine on the human stomach, duodenum, and jejunum in vitro. Gut, 6, 338-342.

Gaddum, J. H., and Hameed, K. A. (1954). Drugs which antagonize 5-hydroxytryptamine. Brit. J. Pharmacol., 9, 240-248.

—_, and Picarelli, Z. P. (1957). Two kinds of tryptamine receptors. Ibid., 12, 323-328.

Gershon, M. D. (1967). Effects of tetrodotoxin on innervated smooth muscle preparations. Ibid., 29, 259-279.

Kuriyama, H., Osa, T., and Toida, N. (1966). Effect of tetrodotoxin on smooth muscle cells of the guinea-pig taenia coli. Ibid., 27, 366-376.

Martinson, J. (1965a). Vagal relaxation of the stomach. Expcrimental re-investigation of the concept of the transmission mechanism. Acta physiol. scand., 64, 453-462.

(1965b). Studies on the efferent vagal control of the stomach. Ibid., 65, suppl. 255.
Narahashi, T., Moore, J. W., and Scott, W. R. (1964). Tetrodotoxin blockade of sodium conductance increase in lobster giant axons. J. gen. Physiol., 47, 965-974.

Paton, W. D. M., and Vane, J. R. (1963). An analysis of the responses of the isolated stomach to electrical stimulation and to drugs. J. Physiol. (Lond.), 165, 10-46.

Robertson, P. A. (1953). An antagonism of 5-hydroxytryptamine by atropine. Ibid., 121, 54-55P.

Rocha E Silva, M., Valle, J. R., and Picarelli, Z. P. (1953). A pharmacological analysis of the mode of action of serotonin (5-hydroxytryptamine) upon the guinea-pig ileum. Brit. J. Pharmacol., 8, 378-388.

Ulrich. K. (1965). A direct and indirect action of 5-hydroxytryptamine on the distal part of the isolated colon of the rat. J. Pharm. Pharmacol.. 17, 710-720.

Whitney, B. (1965). A preliminary investigation of the pharmacology of longitudinal muscle strips from human isolated jejunum. Ibid., 17, 465-473. 